\title{
Formulas for calculating ice cover thickness on selected spring lakes on the upper Radunia (Kashubian Lakeland, northern Poland)
}

\author{
Katarzyna Barańczuk*, Jacek Barańczuk \\ Department of Limnology, University of Gdansk, Bażyńskiego 4, 80-309 Gdańsk, Poland, \\ e-mail: katarzyna.baranczuk@phdstud.ug.edu.pl (" ${ }^{*}$ corresponding author, K.B.); jacek.baranczuk@ug.edu.pl (J.B.)
}

\begin{abstract}
This publication is to confirm the existence of a correlation between lakes under hydrometric supervision and unmonitored lakes using formulas for calculating thickness of ice cover observed on lakes located within the same physico-geographical unit. The article presented herein covers lakes located on the upper Radunia River in the central part of the Kashubian Lakeland. Lake Raduńskie Górne has been under constant hydrometric supervision of the Limnological Station of Gdańsk University for over 60 years. The study covers three spring lakes: Stężyckie, Bukrzyno Małe and Lubowisko. The cover thickness was measured during the period of 2003-2006 and in 2016. Analysing the measurement data gathered during field research and the data obtained from the station allowed formulas for calculating ice cover thickness to be established. The formulas were tested in 2016 with the use of the fieldwork data. The result confirmed that the formulas can be used to calculate thickness of ice cover with considerable accuracy.
\end{abstract}

Key words: spring lake, ice, ice thickness, trend analysis

\section{Introduction}

Lakes are the main natural elements of a glacial landscape. The lakes of the Kashubian Lakeland have been monitored and investigated for many years and a considerable amount of data has been collected so far. The lakes are diverse in terms of depth and area (Barańczuk and Marchlewicz 2003). They also have different hydrological regimes (Borowiak and Barańczuk 2004; Barańczuk and Borowiak 2005; Maślanka and Barańczuk 2007) that affect the ice phenomena observed on them.

Ice phenomena, understood as the emergence of ice particles both on and beneath the surface of water after a prolonged period of belowfreezing temperatures, are one of the key indicators of annual fluctuations of energy conditions characterising lakes located within the temperate climate zone (Choiński 1995; Skowron 2011; Barańczuk and Borowiak 2005). Ice cover is the most frequently analysed parameter related to ice phenomena re- search conducted in the Kashubian Lakeland in the second decade of the 21 st century (Barańczuk et al. 2017; Barańczuk 2018; Barańczuk and Barańczuk 2018; Barańczuk 2019; Barańczuk and Barańczuk 2019). Usually, only lakes under hydrometric supervision are analysed (Skowron 2011, Barańczuk et al. 2017; Barańczuk 2018; Barańczuk and Barańczuk 2019). The cases of lakes not constantly monitored are rather infrequent (Barańczuk and Barańczuk 2018). Such analyses require regular fieldwork research. In fact, the course of ice phenomena is not sufficiently recognised within some specific catchment areas. In order to analyse and monitor the current course of ice phenomena in such areas, satellite images and calculations using empirical formulas are used (Barańczuk and Borowiak 2005; Barańczuk 2015; Barańczuk and Barańczuk 2018; Barańczuk 2019).

Ice cover in the catchment area of the upper Radunia River is constantly monitored on two lakes (benchmark lakes): Ostrzyckie and Raduńskie Górne 
(Barańczuk et al. 2017; Barańczuk 2018; Barańczuk and Barańczuk 2019). However, analyses of the spatial course of ice phenomena with the use of empirical formulas have not been frequently carried out in this area. So far, only one study on this issue has been published (Barańczuk and Barańczuk 2018) and it is focused on models used for calculating ice cover thickness on selected endorheic lakes of the upper Radunia River. As the results of the above-mentioned study were very promising and the correlation between the benchmark lakes and the endorheic ones was significant, other questions arise: What is the course of ice phenomena on spring lakes located within the same catchment area? Is it possible to use the hydrometrically controlled Lake Raduńskie Górne as a benchmark lake for analysing the course of ice phenomena on spring lakes (not being monitored) of the upper Radunia River? Answering these questions will definitely contribute to knowledge on ice phenomena observed on lakes located within the catchment area of the upper Radunia River.

\section{Study area}

In order to answer the research questions, three spring lakes located in the catchment of the upper Radunia River were selected. They are all in the spring area of this catchment that is a part of the Kashubian Lakeland.

Lake Stężyckie and its catchment is, as well as the other selected waterbodies, a spring area of the Radunia River (Fig. 1). It is the north-westernmost water body of the Raduńsko-Ostrzyckie riverlake system and one of the smallest in the system (Barańczuk 2007). Lake Bukrzyno Małe is located in the central part of the same lake-river system and its waters flow through Lake Bukrzyno Duże, which is connected to the Raduńsko-Ostrzyckie lake-river system through the northern part of Lake Ostrzyck- ie. Lake Lubowisko is the south-westernmost lake in the above-mentioned system.

According to the regionalisation by Gacki and Szukalski (1979), Lake Stężyckie, Lake Bukrzyno Małe, Lake Lubowisko and Lake Radunskie Górne (benchmark lake) are located within the Central Uplands and Lakeside Hills (Centralne Wysoczyzny i Wzgórza Nadjeziorne) submesoregion included into the mesoregion of Kashubian Lakeland. Additionally, Lake Stężyckie is part of a microregion called Stężyca Depression (Obniżenie Stężyckie), Lake Bukrzyno Małe is part of the microregion Bukrzyno-Ostrzyce Subglacial Valley (Rynna BukrzyńskoOstrzycka), Lake Lubowisko is part of the microregion Gołubie Subglacial Valley (Rynna Gołubieńska), and the benchmark lake is part of the microregion Radunia Subglacial Valley (Rynna Raduńska).

The morphometric parameters of the benchmark lake are much higher than the ones characterising the analysed lakes (Table 1). When it comes to area, Lake Raduńskie Górne is the largest (387.2 ha) of the selected lakes (Borowiak and Barańczuk 2006; Trusewicz et al. 2009) while Lake Bukrzyno Małe is the smallest (15.5 ha). As for volume, the situation is similar - Lake Raduńskie Górne is the largest with a volume of 60158.7 dam $^{3}$ and Bukrzyno Małe lake is the smallest having a volume of 440 dam $^{3}$ (Barańczuk and Marchlewicz 2003). The maximum depth varies from 43.0 (Lake Raduńskie Górne) to $4.1 \mathrm{~m}$ (Bukrzyno Małe Lake) (Borowiak and Barańczuk 2004).

\section{Research methods}

The research methods implemented for the purpose of this study included several different actions. The most important was fieldwork research during which the data required for establishing empirical formulas was collected. The measurements were made simultaneously (at the shortest possible

Table 1. Morphometric characteristics of the lakes under study

\begin{tabular}{|c|c|c|c|c|}
\hline \multirow{2}{*}{ Lake } & Surface area & Volume & Max. depth & Mean depth \\
\hline & {$\left[\mathrm{hm}^{2}\right]$} & {$\left[\mathrm{dam}^{3}\right]$} & [m] & [m] \\
\hline Raduńskie Górne & 387.2 & 60158.7 & 43.0 & 15.5 \\
\hline Stężyckie & 61.6 & 2348.0 & 11.7 & 3.8 \\
\hline Bukrzyno Małe & 15.5 & 440.0 & 4.1 & 2.5 \\
\hline Lubowisko & 34.3 & 1396.3 & 7.6 & 4.9 \\
\hline
\end{tabular}


intervals) on all lakes during the period of 20032008. The thickness of ice cover formed on the surface of the selected spring lakes was measured 17 times. The measurements were taken 15 metres from the shore with an accuracy of $0.5 \mathrm{~m}$. They were performed in accordance with the guidelines issued by the Institute of Meteorology and Water Managements (IMWM).

In order to establish the empirical formulas, data obtained from the Limnological Station of Gdańsk University was also used. The data concerned thickness of ice cover observed on the benchmark lake. The measuring point is located 100 metres from the station. Measurements are performed every day according to the guidelines issued by the IMWM, yet no information concerning ice type or structure is recorded. The measurements are performed in the period beginning when the whole lake surface is covered with ice and it is safe to go onto it (Barańczuk and Barańczuk 2018).
The data obtained from the station was analysed and compared with the fieldwork data collected in 2016.

\section{Results}

Diagrams were used in order to determine the relationship between the thickness of ice cover on the spring lakes (not being monitored, for which the data was collected during the fieldwork research) and the thickness of ice cover observed on the benchmark lake (Lake Raduńskie Górne). The analysis confirmed that there is a strong correlation between the selected spring lakes and the benchmark lake, all located in the catchment area of the upper Radunia River (Fig. 2).

The analysis of thickness of ice observed on Lake Stężyckie (ICTSt), which is the north-westernmost water body of the Raduńsko-Ostrzyckie lake-river system, and the ice observed on Lake

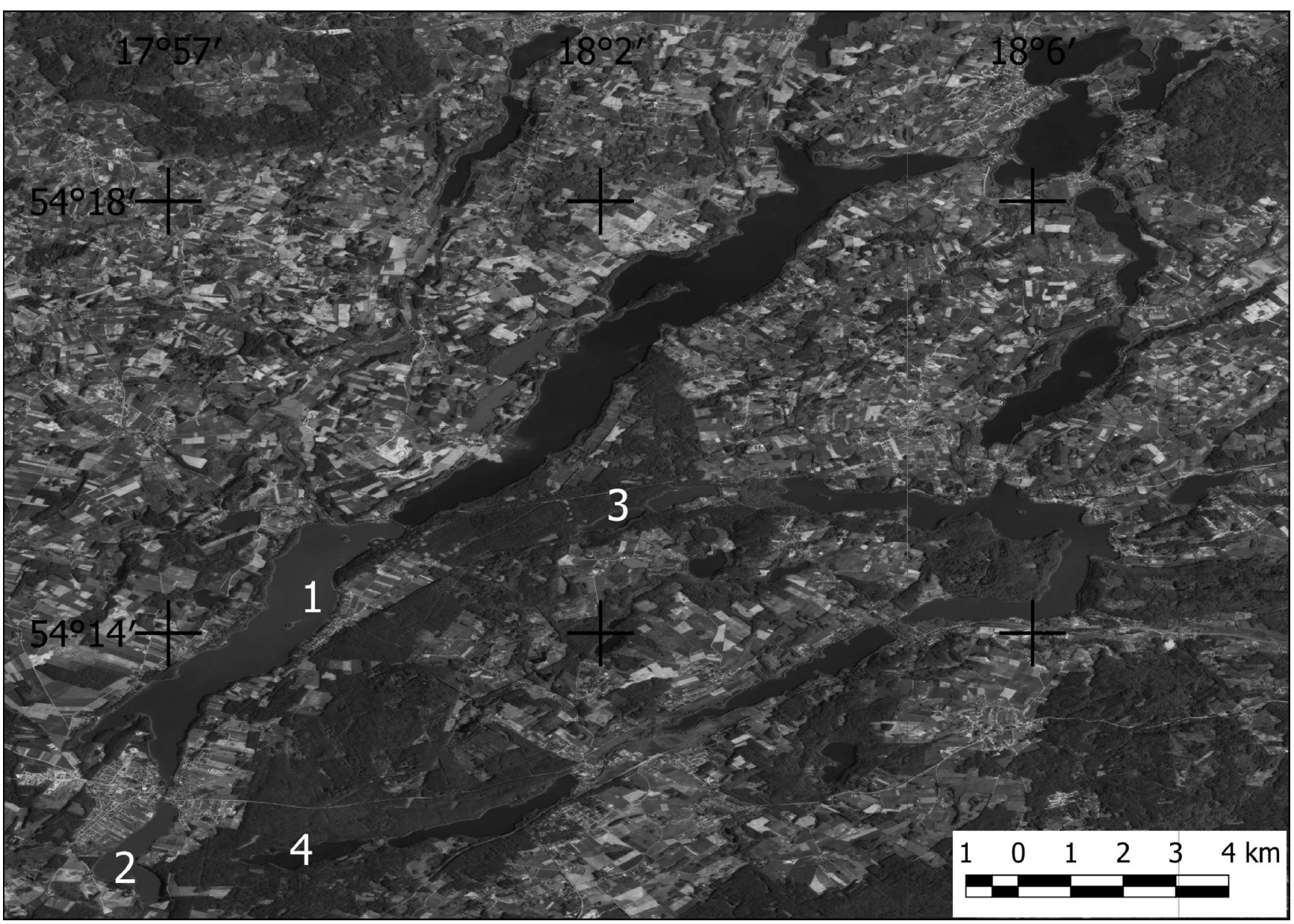

Fig. 1. Location map of the studied lakes: 1 - Lake Raduńskie Górne, 2 - Lake Stężyckie, 3 - Lake Bukrzyno Małe, 4 - Lake Lubowisko 

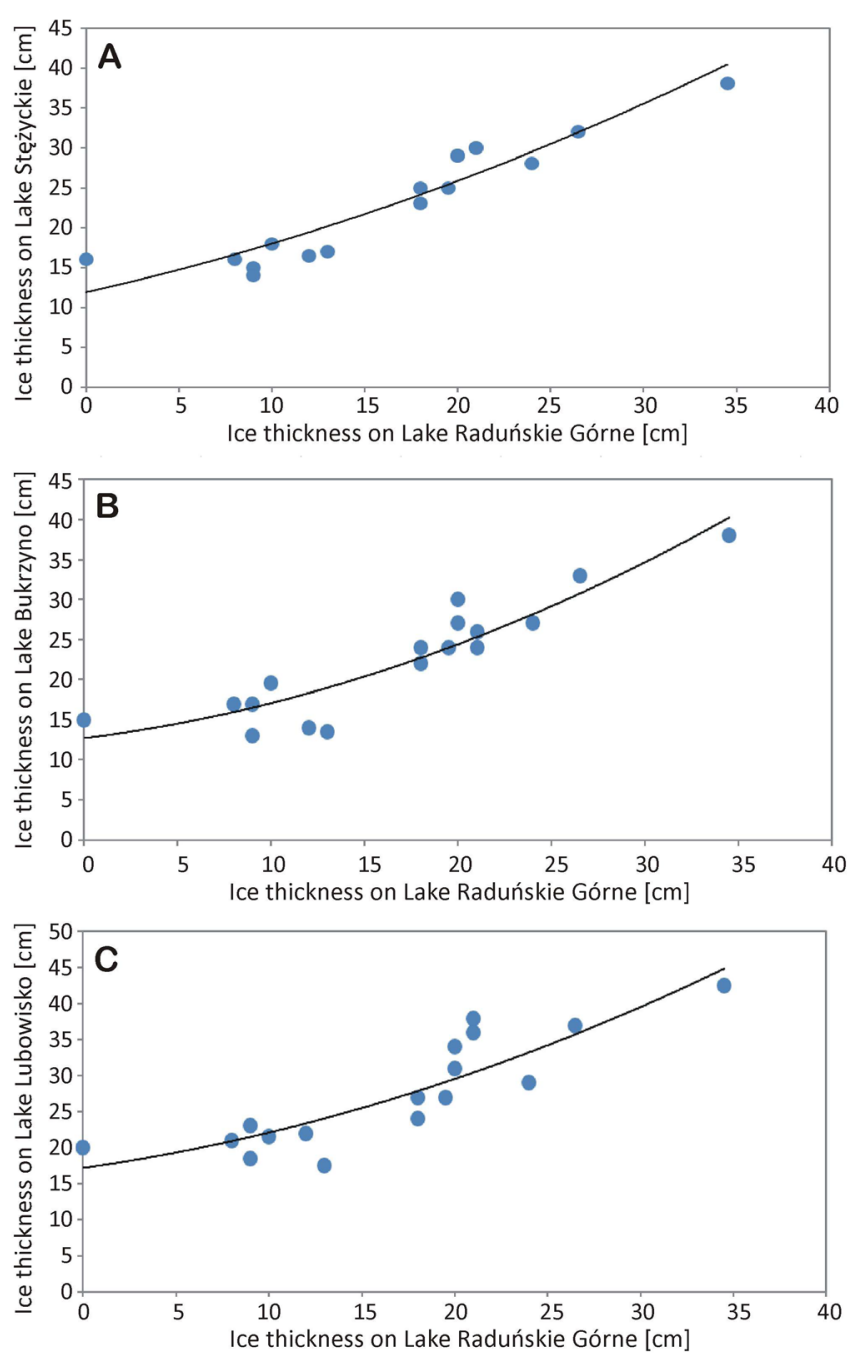

Fig. 2. The ice cover thickness on the research lakes: Stężyckie (A), Bukrzyno Małe (B), and Lubowisko (C) in relation to the ice cover thickness on the benchmark Lake Raduńskie Górne

Raduńskie Górne (ICTRG) showed that in this case the correlation coefficient $(R)$ was the highest of all the analysed cases, reaching the value of 0.937 . It also means that there is a strong relationship between those two lakes and the course of ice phenomena is very similar on both analysed water bodies (Fig. 2A). According to the elaborated model (Table 2), whilst the ice cover emerges on Lake Raduńskie Górne, the ice thickness on Lake Stężyckie is already about $12 \mathrm{~cm}$. However, the actual records slightly differ from the calculated results. The fieldwork research showed that the ice on Lake Stężyckie may reach a thickness of $16 \mathrm{~cm}$ (Fig. 2A).

The second analysed spring lake (Fig. 2B),
Lake Burzyno Małe (ICTBuM), is the smallest one selected (Table 1). Taking the size of this water body into consideration, it is not surprising that the correlation between the ice thickness on this lake and the benchmark lake is not that strong. Nevertheless, it is still quite high: $R=0.920$. According to the model (Table 2), the ice on Lake Burzyno Małe is one centimetre thicker than on Lake Stężyckie at the time when the ice cover has just emerged on the benchmark lake. However, the fieldwork research showed that it was not one, but two centimetres thicker in 2016 (Fig. 2B).

There is also a strong correlation between the thickness of ice forming on the surface of the benchmark lake (Fig. 2C) and the ice cover observed on Lake Lubowisko (ICTLu), which is the south-westernmost lake in the system. In this case the correlation coefficient $(R)$ is 0.874 and it is the lowest value among the analysed lakes. According to the model (Table 2), the ice on Lubowisko Lake is much thicker $(17.5 \mathrm{~cm})$ than on the other analysed spring lakes at the time when the ice cover on the benchmark lake begins to form. However, the fieldwork research showed that the actual thickness was higher by 2.5 $\mathrm{cm}$.

\section{Discussion}

The Kashubian Lakeland is a region with a typical young glacial landscape with numerous lakes and endorheic areas. Ice cover formation is one of the characteristic annual processes that take place in this region (Barańczuk and Marchlewicz 2003; Borowiak and Barańczuk 2004; Marszelewski and Skowron 2009; Choiński et al. 2014; Barańczuk 2015; Solarski et al. 2011) with several exceptions when there was no ice cover at all (Marszelewski and Skowron 2009; Barańczuk et al. 2017).

Nonetheless, research on ice phenomena concerns several different parameters (Assel 2004; Duguay et al. 2006; Ghanbari 2009; Lei et al. 2012; Cheng et al. 2014; Ptak et al. 2019). Some of the researchers focus on changes observed in ice cover resulting from increasingly lengthy observation periods and noticeable changes in specific parameters characterising ice phenomena (Franssena et al. 2008; Skowron 2011; Gebre 2014). Others study ice phenomena in certain regions sharing similar climate conditions where ice phenomena are affected by local weather conditions and morphometric pa- 
Table 2. Ice cover thickness models for the spring lakes of the upper Radunia catchment area constructed on the basis of the ice cover data regarding the benchmark lake Raduńskie Górne. Explanations: ICT $_{\mathrm{RG}}$ - the ice cover thickness on Lake Raduńskie Górne, $\mathrm{ICT}_{\mathrm{St}}$ - the ice cover thickness on Lake Stężyckie, $\mathrm{ICT}_{\mathrm{BM}}$ - the ice cover thickness on Lake Bukrzyno Małe, ICT ${ }_{\mathrm{Lu}}-\mathrm{the}_{\mathrm{ice}}$ cover thickness on Lake Lubowisko. Ice cover thickness is given in centimetres

\begin{tabular}{ccc}
\hline \multicolumn{1}{c}{ Lake } & Model & Determination coefficient \\
\hline Stężyckie & $\mathrm{ICT}_{\mathrm{St}}=0.0089\left(\mathrm{ICT}_{\mathrm{RC}}\right)^{2}+0.5199 \mathrm{CT}_{\mathrm{RG}}+11.91$ & 0.878 \\
Bukrzyno Małe & $\mathrm{ICT}_{\mathrm{BM}}=0.0147\left(\mathrm{ICT}_{\mathrm{RG}}\right)^{2}+0.2902 \mathrm{ICT}_{\mathrm{RG}}+12.714$ & 0.847 \\
Lubowisko & $\mathrm{ICT}_{\mathrm{Lu}}=0.0127\left(\mathrm{ICT}_{\mathrm{RG}}\right)^{2}-0.3655 \mathrm{ICT}_{\mathrm{RG}}+17.147$ & 0.764 \\
\hline
\end{tabular}

rameters of certain water bodies (Kainz et al. 2017; Pointner et al. 2018; Murfitt et al. 2018; Sharma and Woolway 2020). However, there is still little knowledge about regional monitoring of lakes. That is why the monitoring of lakes not under hydrometric supervision is a particularly interesting issue. Such studies usually involve analysing ice cover with the use of satellite images or remote video monitoring data (Murfitt and Duguay 2020; Prabha et al. 2020) and then ice models are created using such indirectly collected data sets (Tom et al. 2020). There are only a few publications on monitoring lakes that are under hydrological control with the use of benchmark lakes (Barańczuk and Barańczuk 2018; Barańczuk 2019).

After analysing the results obtained by the model it can be stated that the strength of the relationship between the analysed spring lakes and the benchmark lake is considerable. Therefore, the results may be classified as promising. The strength of the relationship varies from good to satisfactory with $R^{2}$ lying within the range 0.764 to 0.878 . The strength of the relationship calculated for Lake Lubowiskie $\left(R^{2}=0.764\right)$ is slighter than for Lake Stężyckie $\left(R^{2}=0.878\right)$ and it is depicted by a less linear arrangement of the points visible on the graph in Figure $2 \mathrm{C}$. The model constructed for the endorheic lakes in the catchment area of the upper Radunia River (Barańczuk and Barańczuk 2018) provided slightly better results: $\mathrm{R}^{2}=0.793$ for Lake Zamkowisko and 0.932 for Lake Boruckie. In this case, the strength of relationship varied from satisfactory to very good. This means that only $7 \%$ of the calculated thickness of ice cover is different from the actual values, while in the case of Lake Stężyckie - $12.2 \%$. As Choiński et al. (2015) have shown, a weaker strength of connection, except a local temperature variation, might be responsible for the individual morphometric features (lake volume and depth) of individual lakes. The results were even better for the models concerning the selected lakes of the upper Łeba River (Barańczuk 2019). In this case, the strength of relationship varied from good to very good with $R^{2}=0.881$ for Lake Łapalickie and 0.929 for Lake Reskowskie.

After comparing the data obtained by the model with the data collected during the fieldwork research it has become clear that they do not match (Table 3). The fieldwork data values were higher by $1.6 \mathrm{~cm}$ for Lake Stężyckie and by $4.3 \mathrm{~cm}$ for Lake Bukrzyno Małe. When expressed as a percentage, this is a maximum $19.5 \%$ difference. This result is very similar to the one obtained in the case of the endorheic lakes of the upper Radunia River (20\%)

Table 3. Observed (OBS) and calculated (MRG), on the basis of the models listed in Table 2, values of the ice cover thickness in selected days of the winter season of 2016. All values are given in centimetres

\begin{tabular}{ccccc}
\hline \multirow{2}{*}{ Date } & Type of data & \multicolumn{3}{c}{ Lake } \\
\cline { 3 - 4 } & & Stężyckie & Bukrzyno Małe & Lubowisko \\
\hline \multirow{2}{*}{ 09 JAN 2016 } & OBS & 21.0 & 22.0 & 26.0 \\
& MRG & 18.7 & 17.7 & 22.7 \\
17 JAN 2016 & OBS & 21.0 & 22.0 & 26.0 \\
& MRG & 19.4 & 18.3 & 23.3 \\
20 JAN 2016 & OBS & 23.0 & 23.0 & 27.0 \\
& MRG & 20.9 & 19.6 & 24.7 \\
\hline
\end{tabular}


(Barańczuk 2019). A slightly higher difference, 21\%, was observed in the case of the lakes located in the catchment area of the upper Łeba River (Barańczuk and Barańczuk 2018). However,there is only a $1.5 \%$ difference in comparison to the examples selected for this study.

Therefore, although the values calculated using the model do not entirely match the fieldwork data, the determination coefficient $\left(R^{2}\right)$ values may be classified as relatively high and significant.

\section{Conclusion}

To sum up, the results of the analysis presented herein confirm that the models constructed for the purpose of this study are useful tools for spatial analyses of changes in ice cover formation on the selected lakes. The results are also in line with previous analyses regarding the lakes of the upper Łeba River (Barańczuk and Barańczuk 2019), the endorheic lakes of the upper Radunia River (Barańczuk 2018) and the benchmark lakes published by Barańczuk in 2018. The models allow for a more detailed spatial analysis of changes in the thickness of ice cover forming on different lakes as well as it makes it possible to monitor the spatial diversity of this parameter. The fact that data for the benchmark lake (Raduńskie Górne) is collected on a daily basis and published in real time by the Limnological Station of Gdańsk University makes it possible to establish a real-time model for calculating the spatial diversity of ice cover thickness in the selected region with no need to carry out time-consuming fieldwork research on lakes that are not under hydrological supervision.

\section{References}

Assel R., 2004, Lake Erie ice cover climatology - Basin averaged ice cover: winters 1898-2002. NOAA Technical Memorandum GLERL-128, NOAA Great Lakes Environmental Research Laboratory, Ann Arbor, $15 \mathrm{pp}$.

Barańczuk J., 2007, Jezioro Stężyckie (Lake Stężyckie), [in:] Borowiak D. (ed.), Atlas jezior Kaszubskiego Parku Krajobrazowego (Atlas of the Kashubian Landscape Park Lakes), Ser. Bad. Limnol. 4. Wydaw. KLUG, Gdańsk: 261-266 (in Polish, English summary).

Barańczuk J., 2015, Przebieg zjawisk lodowych na wybranych jeziorach Pojezierza Kaszubskiego (The course of ice phenomena on the selected lakes of the Kashubian Lakeland) [Dissertation], University of
Gdańsk, Gdańsk, 231 pp (in Polish).

Barańczuk J., 2018, The statistical relation/coherence between ice-regimes of Lake Raduńskie Górne and Lake Ostrzyckie, Limnol. Rev. 18(3): 103-108.

Barańczuk J., 2019, Ice cover thickness formulas for selected flow-through lakes of the upper Łeba River (Kashubian Lakeland, northern Poland) and an overview of GIS methods, models for determining the thickness of ice cover on the selected examples, Limnol. Rev. 19(2): 49-55.

Barańczuk J., Marchlewicz R., 2003, Diversity of development of ice phenomena in chosen lakes of Kaszubskie Lakeland in winter 2003, Limnol. Rev. 3: 25-30.

Barańczuk J., Borowiak D., 2005, Zjawiska lodowe jezior (Lakes ice cover), [in:] Lange W. (ed.), Jeziora górnej Raduni $\mathrm{i}$ jej zlewnia w badaniach $\mathrm{z}$ udziałem Stacji Limnologicznej w Borucinie (Lakes of the upper Radunia River and its catchment in research with the participation of the Limnological Station in Borucino), Ser. Bad. Limnol. 3, Wydaw. KLUG, Gdańsk: 251-260 (in Polish, English summary).

Barańczuk J., Bajkiewicz-Grabowska E., Barańczuk K., Staszek W., 2017, The ice regime of Lake Raduńskie Górne (Kashubian Lakeland, northern Poland), Limnol Rev. 17(2): 61-70.

Barańczuk J., Barańczuk K., 2018, Models for calculating ice cover thickness on selected endorheic lakes of the upper Radunia (Kashubian Lakeland, northern Poland), Limnol. Rev. 18(4): 129-135.

Barańczuk K., Barańczuk J., 2019, The ice regime of Lake Ostrzyckie (Kashubian Lakeland, northern Poland), Limnol. Rev. 19(3): 105-112.

Borowiak D., Barańczuk J., 2004, Secular fluctuations of ice phenomena in Raduńskie Górne Lake, Kashubian Lakeland, Limnol. Rev. 4: 17-24.

Borowiak D., Barańczuk J., 2006, Diversity of surface outflow from lakes which perform different hydrological functions, Limnol. Rev. 6: 13-20.

Cheng B., Vihma T., Rontu L., Kontu A., Pour H. K., Duguay C., Pulliainen J., 2014, Evolution of snow and ice tem-perature, thickness and energy balance in Lake Orajärvi, northern Finland, Tellus A 66(1): 1-20.

Choiński A., 1995, Zarys limnologii fizycznej Polski (An outline of physical limnology of Poland), Wydaw. Nauk. UAM, Poznań, 298 pp (in Polish, English summary).

Choiński A., Ptak M., Skowron M., 2014, Tendencje zmian zjawisk lodowych jezior Polski w latach 19512010 (Tendencies of changes of the ice phenomena in Polish lakes in the period 1951-2010), Prz. Geogr. 86(1): 23-40 (in Polish, English summary).

Choiński A., Ptak M., Skowron R., Strzelczak A., 2015, Changes in ice phenology on polish lakes from 1961 to 2010 related to location and morphometry, Limnologica 53: 42-49.

Duguay C.R., Prowse T.D., Bonsal B.R., Brown R.D, Lacroix M.P., Ménard P., 2006, Recent trends in Cana- 
dian lake ice cover, Hydrol. Process. 20: 781-801.

Franssena K.J., Scherrer S.C., 2008, Freezing of lakes on the Swiss plateau in the period 1901-2006, Int. J. Climatol. 28: 421-433.

Gacki T., Szukalski J., 1979, Zróżnicowanie geoekologiczne i regionalne oraz problemy antropizacji i ochrony środowiska geograficznego (Geoecological and regional differentiation, also problems of the anthropization and protection of the Cashubian Lake District geographical environment), [in:] Augustowski B. (ed.) Pojezierze Kaszubskie (Cashubian Lake District), Wydaw. GTN, Gdańsk: 221-253 (in polish, English summary).

Gebre S., Boissy T., Alfredsen K., 2014, Sensitivity of lake ice regimes to climate change in the Nordic region, Cryosphere 8(4): 1589-1605.

Ghanbari R.N., Bravo H.R., Magnuson J.J., Hyzer W.G., Benson B.J., 2009, Coherence between lake ice cover, local climate and teleconnections (Lake Mendota, Wisconsin), J. Hydrol. 374(3-4): 282-293.

Kainz M.J., Ptacnik R., Rasconi S., Hager H.H., 2017, Irregular changes in lake surface water temperature and ice cover in subalpine Lake Lunz, Austria, Inland Waters 7(1): 27-33.

Lei R., Leppäranta M., Cheng B., Heil P., Li Z., 2012, Changes in ice-season characteristics of a European Arctic lake from 1964 to 2008, Clim. Change 115(34): 725-739.

Murfitt J.C., Brown L.C., Howell S.E.L., 2018, Estimating lake ice thickness in Central Ontario, PLoS One 13(12): 1-20.

Murfitt J., Duguay C.R., 2020, Assessing the performance of methods for monitoring ice phenology of the world's largest high Arctic lake using high-density time series analysis of Sentinel- 1 data, Remote Sensing 12(3): 382: 1-26.

Marszelewski W., Skowron R., 2009, Extreme ice phenomena on the lakes of Northern Poland, Limnol. Rev. 9(2-3): 81-89.

Maślanka W., Barańczuk J., 2007, Termika i dynamika wód (Thermicity and dynamics of water), [in:] Borowiak D. (ed.), Jeziora Kaszubskiego Parku Krajobrazowego (Lakes of the Kashubian Landscape Park), Ser. Bad. Limnol. 5, Wydaw. KLUG, Gdańsk: 67-86 (in Polish, English summary).

Pointner G., Bartsch A., Forbes B. C., Kumpula T., 2018, The role of lake size and local phenomena for monitoring ground - fast lake ice, Int. J. Remote Sens. 40(3): 832-858.

Prabha R., Tom M., Roothermel M., Baltsavias E., LealTaixe L., Schindler K., 2020, Lake ice monitoring with webcams and crowd-sourced images, ISPRS Ann. Photogramm. Remote Sens. Spatial Inf. Sci. V-22020: 549-556.

Ptak M., Tomczyk A.M., Wrzesiński D., Bednorz E., 2019, Effect of teleconnecticon patterns on ice conditions in lakes in lowland Poland, Theor. Appl. Climatol. 138(3-4): 1961-1969.

Sharma S., Woolway R.I., 2020, Lake ice [in State of the climate in 2019], Bull. Am. Metorol. Soc. 101(8):S39S41.

Skowron R., 2011, Zróżnicowanie i zmienność wybranych elementów reżimu termicznego wody w jeziorach na Niżu Polskim (Diversity and variability of selected elements of the thermal regime of water in lakes in the Polish Lowlands), Wydaw. Nauk. UMK, Toruń, 345 pp (in Polish, English summary).

Solarski M., Pradela A., Rzętała M., 2011, Natural and anthropogenic influences on ice formation on various water bodies of the Silesian Upland (southern Poland), Limnol. Rev. 11(1): 33-44.

Tom M., Aguilar R., Imhof P., Leinss S., Baltsavias E., Schindler K., 2020, Lake ice detection from Sentinel-1 SAR with deep learning, ISPRS Ann. Photogramm. Remote Sens. Spatial Inf. Sci. V-3-2020: 409-416.

Trusewicz Z., Markowski M., Barańczuk J., 2009, The influence of the North Atlantic Oscillation on variability of surface temperature of Lake Raduńskie Górne, Limnol. Rev. 9(2-3): 55-62. 